Article

\title{
Development of Titanium Dioxide-Supported Pd Catalysts for Ligand-Free Suzuki-Miyaura Coupling of Aryl Chlorides
}

\author{
Tsuyoshi Yamada ${ }^{1}$, Hayato Masuda ${ }^{1}$, Kwihwan Park ${ }^{1}$, Takumu Tachikawa ${ }^{1}$, Naoya Ito ${ }^{1}$, \\ Tomohiro Ichikawa ${ }^{1}$, Masatoshi Yoshimura ${ }^{2}$, Yukio Takagi ${ }^{2}$, Yoshinari Sawama ${ }^{1}$, Yutaka Ohya ${ }^{3}$ \\ and Hironao Sajiki ${ }^{1, *}$ \\ 1 Laboratory of Organic Chemistry, Gifu Pharmaceutical University, 1-25-4 Daigaku-nishi, \\ Gifu 501-1196, Japan; yamada@gifu-pu.ac.jp (T.Y.); hayato.m.gifu@gmail.com (H.M.); \\ kwiffany.p@gmail.com (K.P.); tachi10.3900@gmail.com (T.T.); fwd8821pjl@gmail.com (N.I.); \\ ich.tomo@gmail.com (T.I.); sawama@gifu-pu.ac.jp (Y.S.) \\ 2 Catalysts Development Center, N.E. Chemcat Corporation, 678 Ipponmatsu, Numazu 410-0314, Japan; \\ masatoshi.yoshimura@ne-chemcat.co.jp (M.Y.); Yukio.Takagi@ne-chemcat.co.jp (Y.T.) \\ 3 Department of Chemistry and Biomolecular Science, Gifu University, 1-1 Yanagido, Gifu 501-1193, Japan; \\ ohya@gifu-u.ac.jp \\ * Correspondence: sajiki@gifu-pu.ac.jp; Tel.: +81-230-8100
}

Received: 30 April 2019; Accepted: 17 May 2019; Published: 19 May 2019

\begin{abstract}
The catalyst activities of various heterogeneous palladium catalysts supported by anatase-, rutile- and brookite-type titanium oxide for ligand-free Suzuki-Miyaura cross-coupling reactions of aryl chlorides were evaluated. Palladium acetate $\left[\mathrm{Pd}(\mathrm{OAc})_{2}\right]$, supported on anatase-type titanium oxide $\left(\mathrm{TiO}_{2}\right)$ via acetonitrile solution impregnation process without reduction $\left[\mathrm{Pd} / \mathrm{TiO}_{2}\right.$ (anatase-type)], demonstrated the highest catalyst activity in comparison to those of other titanium oxide (rutileor brookite-type) supported $\mathrm{Pd}(\mathrm{OAc})_{2}$ without reduction and reduced $\mathrm{Pd} / \mathrm{TiO}_{2}$ (anatase-type) $\left[\mathrm{Pd}(\mathrm{red}) / \mathrm{TiO}_{2}\right.$ (anatase-type)]. Various aryl chloride and bromide derivatives were smoothly coupled with arylboronic acids including heteroarylboronic acids in the presence of $5-10 \mathrm{~mol} \% \mathrm{Pd} / \mathrm{TiO}_{2}$ (anatase-type) without the addition of any ligands. Although the fresh $\mathrm{Pd} / \mathrm{TiO}_{2}$ (anatase-type) catalyst was surprisingly comprised of ca. 1:2 mixture of palladium(II) and palladium(0) species according to X-ray photoelectron spectroscopy (XPS), in spite of no reduction process, significant further increment of palladium(0) species was observed during the Suzuki-Miyaura coupling reaction, and $\mathrm{Pd} / \mathrm{TiO}_{2}$ (anatase-type) was converted into a catalyst, which contained palladium(0) species as the main component [ca. 1:5 mixture of palladium(II) and palladium(0) species]. Therefore, the reduction via the electron donation process to the palladium(II) species may have occurred during the reaction on anatase-type titanium oxide.
\end{abstract}

Keywords: Suzuki-Miyaura reaction; palladium; heterogeneous catalyst; titanium oxide; anatase titania; aromatic chloride

\section{Introduction}

Palladium (Pd)-catalyzed Suzuki-Miyaura coupling reaction [1-12] of aryl halides and arylbolonic acid derivatives is one of the most reliable and useful synthetic methods for constructing biaryl derivatives as fundamental skeletons of various biologically active compounds $[2,4,6]$, pharmaceuticals $[2,4]$ and functional materials [5,6]. Various heterogeneous catalysts, including heterogeneous Pd catalysts, have been developed from the perspective of sustainability and process chemistry based on their advantages, such as recoverability, reusability and low residual metal 
property [7-60]. Heterogeneous Pd-catalyzed ligand-free Suzuki-Miyaura coupling reactions have attracted attention as environmentally friendly, metal-contamination-free (or low) and cost-effective methods over the past couple of decades [7-12,17-19]. Particularly, aryl chlorides, which are easily available and less expensive organic compounds in comparison with aryl iodides and bromides, are preferred substrates for the Suzuki-Miyaura coupling reaction, although special ingenuity is necessary for the effective activation of the low-reactive carbon-chloride bond. Therefore, various heterogeneous catalysts have been developed to achieve the heterogeneously catalyzed Suzuki-Miyaura coupling reaction using aryl chlorides [21-40].

Incidentally, the supports for the heterogeneous Pd catalysts are roughly categorized into two. One is ligand-like nitrogen- [21-24,39,40] or phosphine- [25-30] substituted polystyrene-polymers for the purpose of stabilizing the Pd-arene complexes, and/or the enhancement of the catalyst activity based on the coordination effect of the substituent. Furthermore, we developed heterogeneous Pd catalysts immobilized on a ligand-like tertiary amine polystyrene-divinylbenzene-based polymer for the ligand-free Suzuki-Miyaura coupling reaction of aryl chlorides $[39,40]$. The other category is polymers [34] or inorganics [31-33,35-50] without additional and coordinable functionalities, such as activated carbon [31-33], polystyrene [34], metal-organic frameworks [35], polyoxometalate [36] and titanium dioxide $\left(\mathrm{TiO}_{2}\right)$ [42-50].

Some $\mathrm{TiO}_{2}$-supported $\mathrm{Pd}$ catalysts have been applied to various organic and inorganic reactions such as the Suzuki-Miyaura reaction [42-50], hydrogenation [51-58] and Heck reaction [59]. However, the effect on the catalyst activity, depending on the difference of the $\mathrm{TiO}_{2}$ crystal forms of $\mathrm{TiO}_{2}$-supported Pd catalysts toward cross-coupling reactions, has never been systematically evaluated, except for a report related to the oxidative homo coupling reaction of 4-methylpyridines in the presence of $\mathrm{Pd}$ oxide-loaded $\mathrm{TiO}_{2}\left(\mathrm{PdO} / \mathrm{TiO}_{2}\right)$ as a catalyst [60].

In this study, we prepared and investigated the physical properties of the anatase-, rutile- and brookite-type $\mathrm{TiO}_{2}$-supported $\mathrm{Pd}$ catalysts by using X-ray photoelectron spectroscopy (XPS) and transmission electron microscopy (TEM), and comprehensively investigated the effect on the catalyst activities depending on the crystal form of $\mathrm{TiO}_{2}$ to the $\mathrm{TiO}_{2}$-supported Pd-catalyzed ligand-free Suzuki-Miyaura coupling reaction. Consequently, the anatase-type $\mathrm{TiO}_{2}$-supported $\mathrm{Pd}$ catalyst was found to have quite an efficient catalyst activity toward the Suzuki-Miyaura coupling reaction, including the coupling of aromatic chlorides due to the quite highly distributed small $\mathrm{Pd}$ nanoparticles (1-2 nm) on the anatase-type $\mathrm{TiO}_{2}$.

\section{Results and Discussion}

Initially, nine kinds of heterogeneous $\mathrm{TiO}_{2}$-supported Pd catalysts (Table 1, Categories Cat. A-I) were prepared in a manner analogous to the previously established preparation method in our laboratory for a chelate resin-supported heterogeneous Pd catalyst (7\% Pd/WA30) [39-41]. Pd(OAc) which was $5 \mathrm{wt} \%$ of Pd metal equivalent of the usage of $\mathrm{TiO}_{2}$, was embedded on the colorless anatase-, rutile- or brookite-type $\mathrm{TiO}_{2}$ powder by gentle stirring in acetonitrile $(\mathrm{MeCN})$ or ethyl acetate (EtOAc) at $25^{\circ} \mathrm{C}$ for 4 days under argon atmosphere. Colorless $\mathrm{TiO}_{2}$ powders gradually turned to light yellow due to the interaction between $\mathrm{Pd}(\mathrm{OAc})_{2}$ and $\mathrm{TiO}_{2}$; subsequently, the resulting insoluble powder was filtered, washed with EtOAc and $\mathrm{H}_{2} \mathrm{O}$ and dried in vacuo to afford a light yellowish powder (Entries 4-9, $\mathbf{P d} / \mathrm{TiO}_{2}$, Cat. D-I). The Pd content in $\mathrm{Pd} / \mathrm{TiO}_{2}$ (Cat. A-D and F-I) and $\mathrm{Pd}^{-} \mathrm{TiO}_{2}$ (Cat. E) were determined to be approximately $5 \mathrm{wt} \%$ and $4 \mathrm{wt} \%$ by the atomic absorption analysis of the residual $\mathrm{Pd}$ species in the collected organic and aqueous filtrates, respectively.

The filtered $\mathrm{Pd} / \mathrm{TiO}_{2}$ prepared in $\mathrm{MeCN}$ suspension (Entry 4, Cat. D, anatase-type) was stirred at $25^{\circ} \mathrm{C}$ for $24 \mathrm{~h}$ in $\mathrm{H}_{2} \mathrm{O}$ accompanied by hydrazine monohydrate or sodium borohydride, or in EtOAc under hydrogen atmosphere. The filtered resulting powder was sequentially washed with EtOAc and $\mathrm{H}_{2} \mathrm{O}$, and dried under reduced pressure to afford grayish white $\mathrm{Pd}(\mathrm{red}) / \mathrm{TiO}_{2}$ catalysts (Entries 1-3, Cat. A-C, anatase-type). 
Table 1. Preparation of $\mathrm{Pd} / \mathrm{TiO}_{2}$ and $\mathrm{Pd}($ red $) / \mathrm{TiO}_{2}$.

1. $\mathrm{TiO}_{2}$

(Crystalline structure)

\begin{tabular}{|c|c|c|c|c|}
\hline & $\begin{array}{l}\text { (Crystalline structure) } \\
\text { Solvent } \\
\text { Ar, } 25^{\circ} \mathrm{C}, 4 \mathrm{~d}\end{array}$ & & $\begin{array}{l}\text { 1. Reductant } \\
\operatorname{Ar}, 25^{\circ} \mathrm{C}, 24 \mathrm{~h}\end{array}$ & \\
\hline $\mathrm{Pd}(\mathrm{OAc})_{2}$ & $\begin{array}{l}\text { 2. Filtration } \\
\text { 3. Wash with } \\
\text { EtOAc and } \mathrm{H}_{2} \mathrm{O} \\
\text { 4. Vacuum dry }\end{array}$ & $\mathrm{Pd} / \mathrm{TiO}_{2}$ & $\begin{array}{l}\text { 2. Filtration } \\
\text { 3. Wash with } \\
\text { EtOAc and } \mathrm{H}_{2} \mathrm{O} \\
\text { 4. Vacuum dry }\end{array}$ & $\mathrm{Pd}($ red $) / \mathrm{TiO}_{2}$ \\
\hline
\end{tabular}

\begin{tabular}{|c|c|c|c|c|}
\hline Entry & Solvent & $\begin{array}{l}\text { Reductant of } \\
\text { Pd Catalyst }\end{array}$ & Pd Catalyst & Color \\
\hline 1 & $\mathrm{MeCN}$ & $\mathrm{NH}_{2} \mathrm{NH}_{2} \bullet \mathrm{H}_{2} \mathrm{O}^{\mathrm{a}}$ & $\begin{array}{c}5 \% \mathrm{Pd}(\mathrm{red}) / \mathrm{TiO}_{2} \\
\text { (Cat. } \mathbf{A}, \text { anatase-type) }\end{array}$ & Grayish white \\
\hline 2 & $\mathrm{MeCN}$ & $\mathrm{NaBH}_{4}{ }^{\mathrm{a}}$ & $\begin{array}{c}5 \% \mathrm{Pd}(\mathrm{red}) / \mathrm{TiO}_{2} \\
\text { (Cat. B, anatase-type) }\end{array}$ & Grayish white \\
\hline 3 & $\mathrm{MeCN}$ & $\mathrm{H}_{2}{ }^{b}$ & $\begin{array}{c}5 \% \mathrm{Pd}(\mathrm{red}) / \mathrm{TiO}_{2} \\
\text { (Cat. C, anatase-type) }\end{array}$ & Grayish white \\
\hline 4 & $\mathrm{MeCN}$ & - & $\begin{array}{c}5 \% \mathrm{Pd} / \mathrm{TiO}_{2} \\
\text { (Cat. D, anatase-type) }\end{array}$ & Light yellow \\
\hline 5 & EtOAc & - & $\begin{array}{c}4 \% \mathrm{Pd} / \mathrm{TiO}_{2} \\
\text { (Cat. E, anatase-type) }\end{array}$ & Light yellow \\
\hline 6 & $\mathrm{MeCN}$ & - & $\begin{array}{c}5 \% \mathrm{Pd} / \mathrm{TiO}_{2} \\
\text { (Cat. F, rutile-type) }\end{array}$ & Light yellow \\
\hline 7 & EtOAc & - & $\begin{array}{c}5 \% \mathrm{Pd} / \mathrm{TiO}_{2} \\
\text { (Cat. G, rutile-type) }\end{array}$ & Light yellow \\
\hline 8 & $\mathrm{MeCN}$ & - & $\begin{array}{c}5 \% \mathrm{Pd} / \mathrm{TiO}_{2} \\
\text { (Cat. } \mathbf{H}, \text { brookite-type) }\end{array}$ & Light yellow \\
\hline 9 & EtOAc & - & $\begin{array}{c}5 \% \mathrm{Pd} / \mathrm{TiO}_{2} \\
\text { (Cat. I, brookite-type) }\end{array}$ & Light yellow \\
\hline
\end{tabular}

a The reduction of $\mathrm{Pd} / \mathrm{TiO}_{2}$ (Cat. D, anatase-type) was carried out in $\mathrm{H}_{2} \mathrm{O} .{ }^{\mathrm{b}}$ The reduction of $\mathrm{Pd} / \mathrm{TiO}_{2}($ Cat. D, anatase-type) was carried out in EtOAc.

The XPS analysis of the $\mathrm{Pd} / \mathrm{TiO}_{2}$ catalysts (Cat. E-I) prepared without reduction processes surprisingly indicated an approximately 2:1 mixture of $\mathrm{Pd}(0)$ species and $\mathrm{Pd}(\mathrm{II})$ ions (Figure 1 ). The characteristic peaks of $\mathrm{Pd}_{3 / 2}$ and $\mathrm{Pd} 3 \mathrm{~d}_{5 / 2}$ and the area $\%$ of $\mathrm{Pd}(0)$ species and $\mathrm{Pd}(\mathrm{II})$ ions are shown in the Supporting Information (Figure S1).

The catalyst activities of various $\mathrm{TiO}_{2}$-supported Pd catalysts (Cat. A-I) for the Suzuki-Miyaura coupling reaction using $4^{\prime}$-chloroacetophenone (1a) and phenylboronic acid (2a) as substrates were evaluated. A portion of each of the catalysts $(5 \mathrm{~mol} \%)$ was added to the mixture of $\mathbf{1 a}(0.25 \mathrm{mmol})$, 2a (1.5 equiv) and cesium carbonate $\left(\mathrm{Cs}_{2} \mathrm{CO}_{3} ; 2.0\right.$ equiv) in dimethylacetamide (DMA; $\left.1 \mathrm{~mL}\right)$ and stirred at $600 \mathrm{rpm}$ for $24 \mathrm{~h}$ at $80^{\circ} \mathrm{C}$ under argon atmosphere (Table 2, Entries 1-10). While the reduced $\mathrm{TiO}_{2}$-supported $\mathrm{Pd}$ catalysts $\left[\mathrm{Pd}(\mathrm{red}) / \mathrm{TiO}_{2}\right.$, (Cat. A-C, anatase-type)] using hydrazine monohydrate, sodium borohydride or hydrogen gas indicated less catalyst efficiencies for the Suzuki-Miyaura coupling reaction (Entries 1-3), the use of $\mathrm{Pd} / \mathrm{TiO}_{2}$ (Cat. $\mathbf{D}$ and $\mathbf{E}$, anatase-type), without the reduction process, afforded biaryls (3a) in relatively good conversion ratios (Entries 4 and 5). The catalyst activities of other $\mathrm{Pd} / \mathrm{TiO}_{2}$ catalysts without reduction process (Cat. F and $\mathrm{G}$, rutile-type, and Cat. I, brookite-type) indicated low to moderate conversion ratios (Entries 6-8), except for Cat. $\mathbf{H}$ (brookite-type), which had a good conversion ratio (65\%, Entry 9). 1a was completely converted to the corresponding 4-acetylbiphenyl (3a) in the presence of $5 \% \mathrm{Pd} / \mathrm{TiO}_{2}$ (Cat. $\mathrm{D}$, anatase-type, $5 \mathrm{~mol} \%$ ) by enhancing the stirring speed to $1000 \mathrm{rpm}$ from $600 \mathrm{rpm}$ (Entry 10), while the coupling reaction was never completed using $5 \% \mathrm{Pd} / \mathrm{TiO}_{2}$ (Cat. I, brookite-type, $5 \mathrm{~mol} \%$ ) at $1000 \mathrm{rpm}$ (Entry 11). Based on these results, the catalytic activity depends in part on the difference of $\mathrm{TiO}_{2}$ crystal forms based on the different interaction properties between $\mathrm{Pd}$ species and $\mathrm{TiO}_{2}$ crystal forms, and the catalytic activities are approximately catalysts $\mathbf{D}$ and $\mathbf{E}$ (anatase type) $>$ catalysts $\mathbf{F}$ and $\mathbf{G}$ (rutile type) $>$ catalysts $\mathbf{H}$ and $\mathbf{I}$ (brookite type) in this order [61-63]. Therefore, $5 \% \mathrm{Pd} / \mathrm{TiO}_{2}$ (Cat. $\mathrm{D}$, anatase-type) indicated quite a high catalyst activity toward the ligand-free Suzuki-Miyaura coupling reaction of aryl chlorides. 

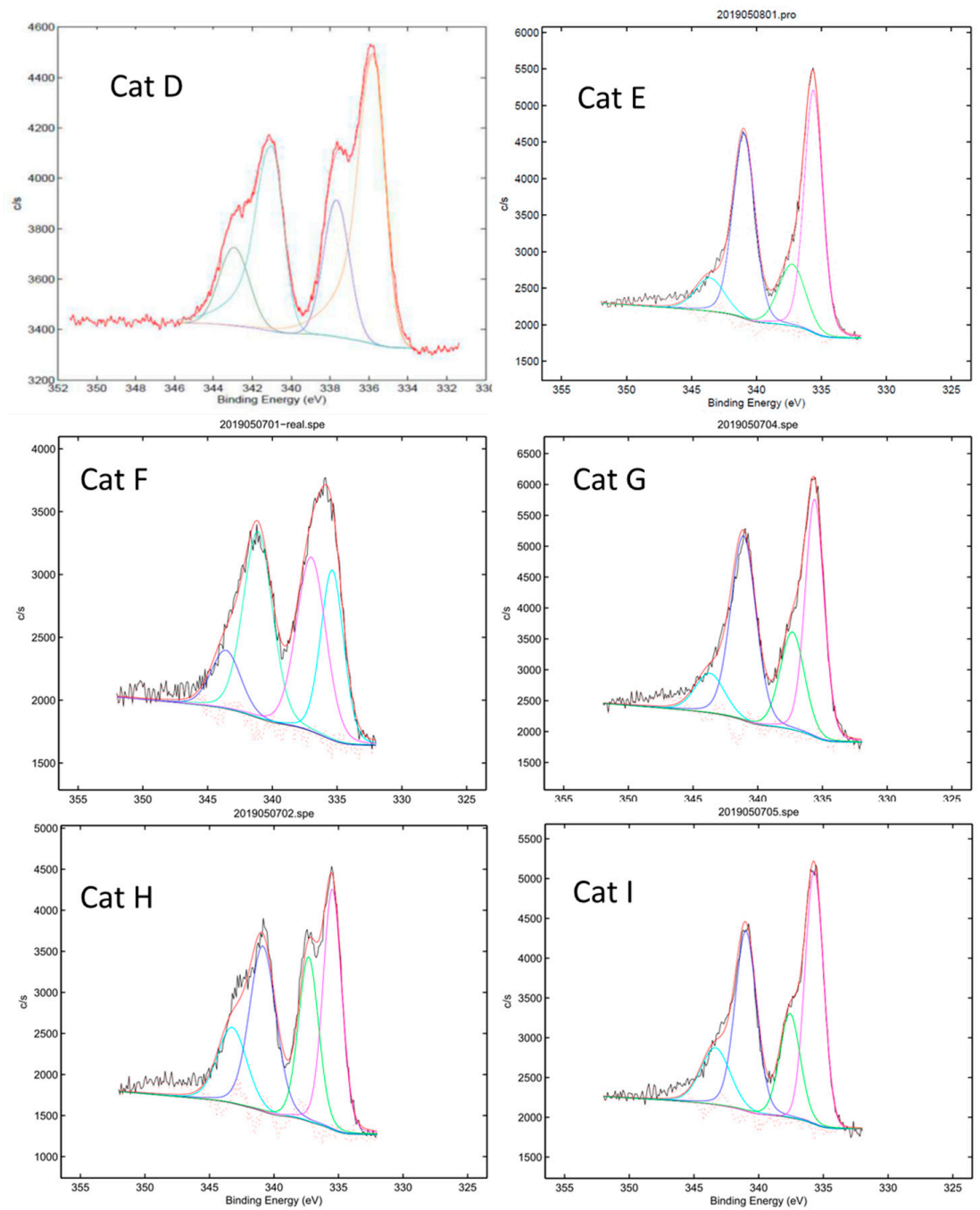

Figure 1. X-ray photoelectron spectroscopy (XPS) spectra of $5 \% \mathrm{Pd} / \mathrm{TiO}_{2}(\mathrm{Cat} . \mathbf{D}$ and $\mathbf{F}-\mathbf{I})$ and $4 \%$ $\mathrm{Pd} / \mathrm{TiO}_{2}$ (Cat. E).

Table 2. Catalyst activity of $\mathrm{TiO}_{2}$-supported Pd catalysts for the Suzuki-Miyaura coupling reaction of $4^{\prime}$-chloroacetophenone (1a) with phenylboronic acid (2a). ${ }^{\text {a }}$

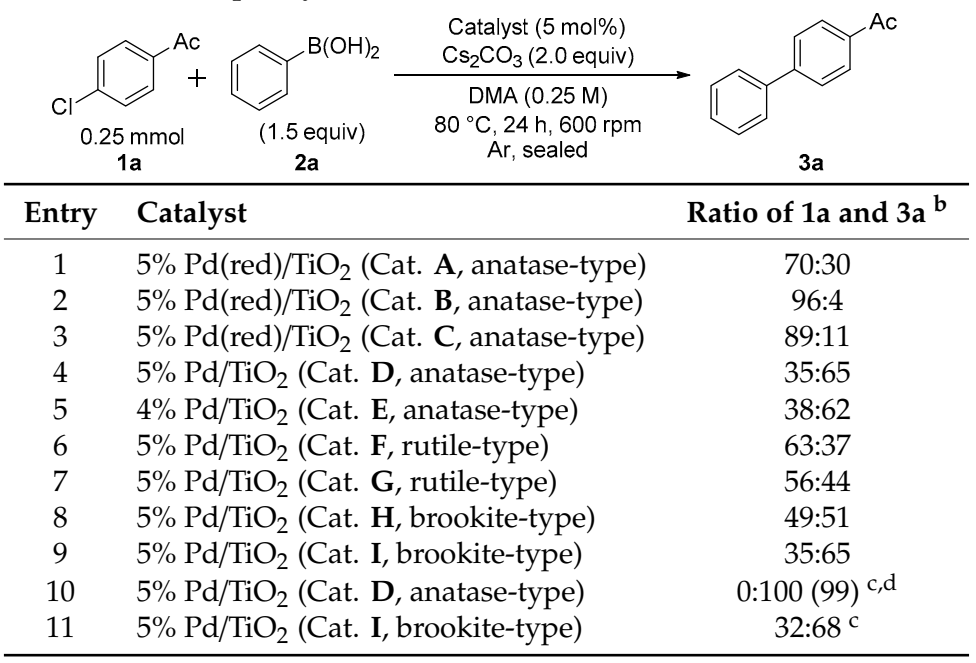

a Reactions were carried out on a $0.25 \mathrm{mmol}$ scale in $1 \mathrm{~mL}$ of dimethylacetamide (DMA). ${ }^{\mathrm{b}}$ Ratios were determined by GC/MS (JEOL JMS Q1000GC Mk II Quad GC/MS). ${ }^{\mathrm{c}}$ The reaction mixture was stirred at $1000 \mathrm{rpm} .{ }^{\mathrm{d}}$ The isolated yield was indicated in parenthesis. 
The catalyst activity of the $5 \% \mathrm{Pd} / \mathrm{TiO}_{2}$ (Cat. D, anatase-type) was compared with other heterogeneous and homogeneous Pd catalysts (Table 3). The quantitative conversion of 1 a could be achieved by using $5 \mathrm{~mol} \%$ of $7 \% \mathrm{Pd} / \mathrm{WA} 30$ developed in our research group [39-41], although high speed and vigorous stirring (1600 rpm) conditions were required (Entry 2). On the other hand, 10\% $\mathrm{Pd}$ on carbon $(\mathrm{Pd} / \mathrm{C})(5 \mathrm{~mol} \%)$ indicated ineffective catalyst activity (Entry 3$)$. Furthermore, some homogeneous Pd catalysts are known to have high catalyst activity in Suzuki-Miyaura coupling reaction [64,65], however, the use of $5 \mathrm{~mol} \%$ of $\mathrm{Pd}(\mathrm{OAc})_{2}$ as a homogeneous catalyst gave only moderate conversion (Entry 4). Therefore, $5 \% \mathrm{Pd} / \mathrm{TiO}_{2}$ (Cat. D) is suitable as an active catalyst for the Suzuki-Miyaura coupling reaction for aryl chlorides.

Table 3. Comparison of the catalyst activity. ${ }^{\text {a }}$

\begin{tabular}{|c|c|c|c|}
\hline $\begin{array}{c}0.25 \mathrm{mmol} \\
1 \mathrm{a}\end{array}$ & (1.5 equiv) & $\begin{array}{c}\text { Catalyst (5 mol\%) } \\
\mathrm{Cs}_{2} \mathrm{CO}_{3}(2.0 \text { equiv) } \\
\mathrm{DMA}(0.25 \mathrm{M}) \\
80^{\circ} \mathrm{C}, 24 \mathrm{~h}, \mathrm{Ar} \text {, sealed }\end{array}$ & $3 a$ \\
\hline Entry & \multicolumn{2}{|c|}{ Catalyst } & Ratio of $1 a$ and $3 a$ \\
\hline 1 & \multicolumn{2}{|c|}{$5 \% \mathrm{Pd} / \mathrm{TiO}_{2}$ (Cat. D, anatase-type) } & $0: 100(99)^{b, c, d}$ \\
\hline 2 & \multicolumn{2}{|c|}{$7 \% \mathrm{Pd} / \mathrm{WA} 30$} & $0: 100^{\text {e }}[35]$ \\
\hline 3 & \multicolumn{2}{|c|}{$10 \% \mathrm{Pd} / \mathrm{C}$} & $97: 3^{e}[35]$ \\
\hline 4 & \multicolumn{2}{|c|}{$\mathrm{Pd}(\mathrm{OAc})_{2}$} & $57: 43^{a, b, c}$ \\
\hline
\end{tabular}

\footnotetext{
a Reactions were carried out on a $0.25 \mathrm{mmol}$ scale in $1 \mathrm{~mL}$ of DMA. ${ }^{\mathrm{b}}$ Ratio was determined by GC/MS (JEOL JMS Q1000GC Mk II Quad GC/MS). ${ }^{c}$ The reaction mixture was stirred at $1000 \mathrm{rpm} .{ }^{\mathrm{d}}$ The isolated yield was indicated in parenthesis. ${ }^{e}$ The reaction mixture was stirred at $1600 \mathrm{rpm}$ under $\mathrm{Ar}$ and the product ratio was determined by ${ }^{1} \mathrm{H}$ NMR using 1,4-dioxane added as an internal standard.
}

Next, we investigated the effects of the reaction temperature and atmospheric conditions in a test tube as a reaction vessel on $5 \% \mathrm{Pd} / \mathrm{TiO}_{2}$ (Cat. D, anatase-type)-catalyzed Suzuki-Miyaura coupling reaction (Table 4). The reaction did not proceed at $25{ }^{\circ} \mathrm{C}$ (Entry 2). While the reaction quantitatively proceeded in a test tube sealed with a septum under argon atmosphere at $80^{\circ} \mathrm{C}$ for $24 \mathrm{~h}$ in Entry 1, the reaction efficiency was drastically decreased under atmospheric exposure (Entry 3). Therefore, the elimination of oxygen from the reaction vessel is strongly required for the $\mathrm{Pd} / \mathrm{TiO}_{2}$ (Cat. D, anatase-type)-catalyzed ligand-free Suzuki-Miyaura coupling reaction of aryl chloride. Further detailed optimization of the base, solvent and reaction time are indicated in the Supporting Information (Tables S1-S3).

Table 4. Effect of various reaction conditions.

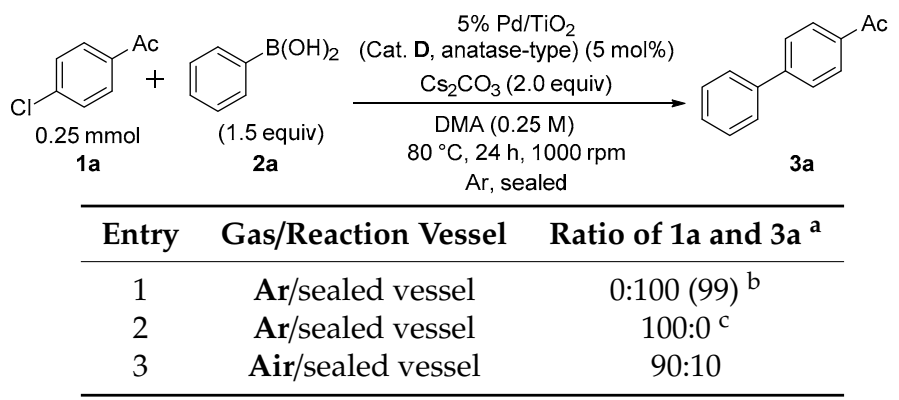

\footnotetext{
a The reaction was carried out in a test tube (the internal volume of $18 \mathrm{~mL}$ ) tightly sealed with a septum under each atmospheric conditions (Ar and Air) and the ratio was determined by ${ }^{1} \mathrm{H}$ NMR using 1,4-dioxane added as an internal standard. ${ }^{b}$ The isolated yield was indicated in parenthesis. ${ }^{c}$ The reaction was performed at $25^{\circ} \mathrm{C}$.
}

The substrate applicability was investigated using $5 \mathrm{~mol} \%$ of $5 \% \mathrm{Pd} / \mathrm{TiO}_{2}$ (Cat. $\mathbf{D}$, anatase-type) and $\mathrm{Cs}_{2} \mathrm{CO}_{3}$ (2 equiv) in DMA at $80{ }^{\circ} \mathrm{C}$ for $24 \mathrm{~h}$ at $1000 \mathrm{rpm}$ (Scheme 1). Aryl chlorides bearing an electron withdrawing group such as $\mathrm{Ac}$ and $\mathrm{EtO}_{2} \mathrm{C}$ on the aromatic ring (1a-1d) efficiently reacted 
with $\mathbf{2 a}$ or 4-acetylphenylboronic acid (2b) regardless of their substitution pattern (3b-3e). Although the coupling of chlorobenzene (1e) with 4-methoxyphenylboronic acid (2c) was inefficient and only a $17 \%$ yield of $3 \mathbf{f}$ was obtained, the reaction efficiency was significantly improved using 2.0 equiv of $\mathrm{KO} t \mathrm{Bu}$ instead of $\mathrm{Cs}_{2} \mathrm{CO}_{3}$. Furthermore, 1a was reacted with 4'-, 3'- or 2'-methoxyphenylboronic acid $(2 \mathrm{c}, \mathbf{2 d}$, or $\mathbf{2 e})$ in moderate to good yields ( $3 \mathbf{g}, \mathbf{3 h}$, or $\mathbf{3 i})$. The direct formation of heterobiaryl skeletons is important for the construction of partial scaffolds of biologically active compounds [66-72] and functional materials [73,74]. The coupling of $4^{\prime}$-chloroacetophenone (1a) with heteroarylboronic acid derivatives afforded the corresponding heterobiaryl derivatives ( $3 \mathbf{j}$ and $\mathbf{3 k}$ ) in moderate to excellent yields. Although $3 \mathbf{f}$ was obtained in a relatively low yield (24\%) using 4-chloroanisole (1f) possessing an electron donating methoxy group on the aromatic ring even by the increased usage of $5 \% \mathrm{Pd} / \mathrm{TiO}_{2}$ (10 $\mathrm{mol} \%$, Cat. D, anatase-type), phenylboronic acid ( $2 \mathbf{a}, 2.0$ equiv) and $\mathrm{Cs}_{2} \mathrm{CO}_{3}$ (3.0 equiv), the use of 4'-methoxyphenylbromide (4a) as an aryl bromide afforded a high yield ( $85 \%)$ of $3 \mathbf{e}$ under the original reaction conditions $\left[5 \% \mathrm{Pd} / \mathrm{TiO}_{2}\right.$ (Cat. $\mathbf{D}$, anatase-type, $5 \mathrm{~mol} \%$ ), $2 \mathbf{a}$ (1.5 equiv) and $\mathrm{Cs}_{2} \mathrm{CO}_{3}$ (2.0 equiv), Equation (1)].

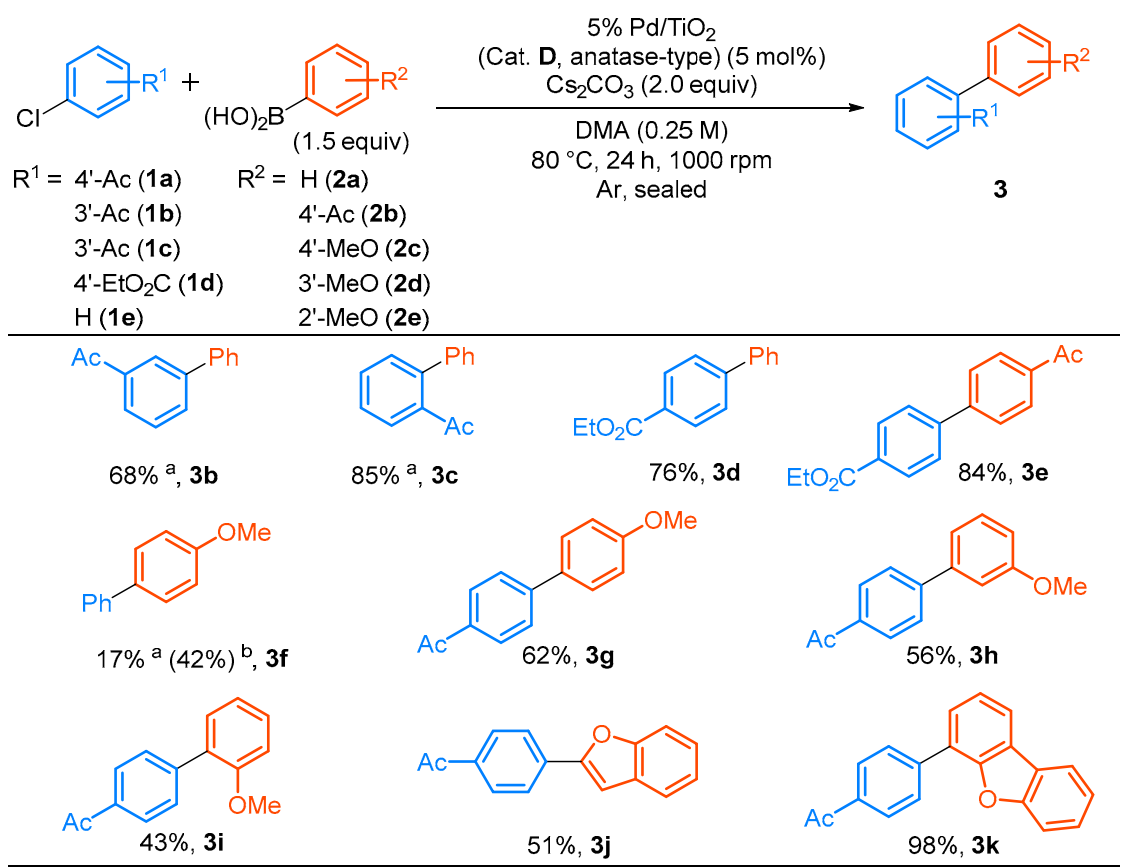

Scheme 1. Scope and limitations of the Suzuki-Miyaura coupling reactions. ${ }^{\text {a }} 2.0$ equiv of an arylboronic acid, $10 \mathrm{~mol} \%$ of $5 \% \mathrm{Pd} / \mathrm{TiO}_{2}$ (Cat. D anatase-type) and 3.0 equiv of $\mathrm{Cs}_{2} \mathrm{CO}_{3}$ were used. ${ }^{\mathrm{b}} 2.0$ equiv of $\mathrm{KO}$ Bu was used instead of $\mathrm{Cs}_{2} \mathrm{CO}_{3}$.

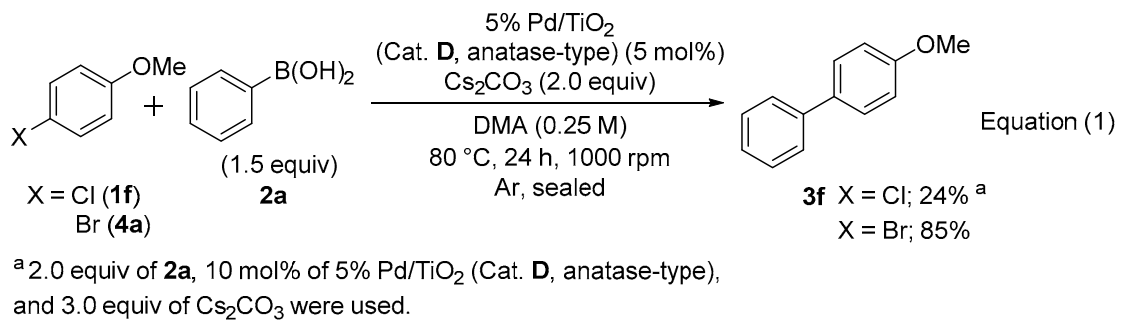

Although one of the advantages of the heterogeneous catalyst is reusability, the catalyst efficiency of $5 \% \mathrm{Pd} / \mathrm{TiO}_{2}$ (Cat. D, anatase-type) recovered after the first Suzuki-Miyaura coupling reaction using 1a and 2a significantly decreased, and the coupling reaction was never completed at $80^{\circ} \mathrm{C}$ even after $24 \mathrm{~h}$ [Equation (2)]. 


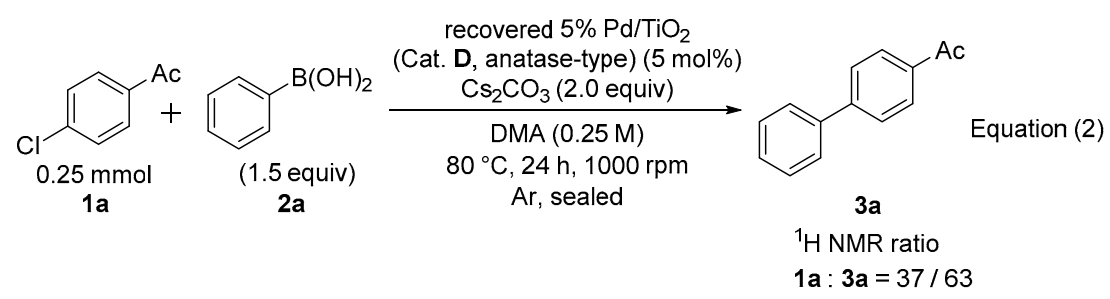

The Pd leaching behavior into the Suzuki-Miyaura coupling reaction medium and the trace Pd contamination in the coupling product after the purification process were examined using atomic absorption spectrometry [AAS, Equation (3)]. As a result, Pd species were never observed in both the reaction media after reaction and the coupling product $3 \mathbf{a}$ after purification including filtration, extraction with EtOAc and silica-gel column chromatography.

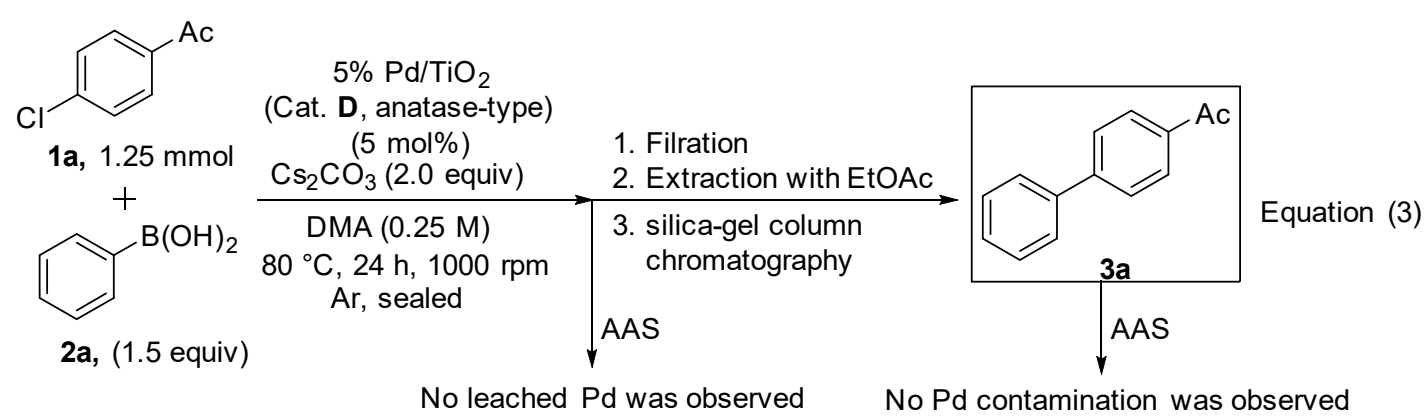

Although the fresh $5 \% \mathrm{Pd} / \mathrm{TiO}_{2}$ (Cat. $\mathrm{D}$, anatase-type) without any reduction processes during the preparation amazingly consisted of ca. 1:2 mixture of $\mathrm{Pd}$ (II) ion (characteristic peaks at ca. 342.9 and $337.7 \mathrm{eV}$ for $\mathrm{Pd} 3 \mathrm{~d}_{3 / 2}$ and $\mathrm{Pd} 3 \mathrm{~d}_{5 / 2}$ ) and $\mathrm{Pd}(0)$ species (characteristic peaks at ca. 341.0 and $335.7 \mathrm{eV}$ for $P d 3 d_{3 / 2}$ and $P d 3 d_{5 / 2}$ ) according to XPS (Figure 2a), a significant increment in $\mathrm{Pd}(0)$ species (characteristic peaks at ca. 340.1 and $334.9 \mathrm{eV}$ for $\mathrm{Pd}_{3 \mathrm{~d}_{3 / 2}}$ and $\mathrm{Pd} 3 \mathrm{~d}_{5 / 2}$ ) was observed and the recovered $5 \% \mathrm{Pd} / \mathrm{TiO}_{2}$ (Cat. D, anatase-type) was composed of ca. 1:5 mixture of $\mathrm{Pd}(\mathrm{II})$ ion (characteristic peaks at ca. 341.6 and $336.4 \mathrm{eV}$ for $\mathrm{Pd} 3 \mathrm{~d}_{3 / 2}$ and $\left.\mathrm{Pd} 3 \mathrm{~d}_{5 / 2}\right)$ and $\mathrm{Pd}(0)$ species after the coupling reaction [Figure $2 \mathrm{~b}$ ]. From these results, $\mathrm{Pd}(\mathrm{II})$ species might be reduced by the significant electron donation during the Suzuki-Miyaura coupling reaction, probably due to the interaction between Pd species and a mass of $\mathrm{TiO}_{2}$ via metal-support interaction [strong metal support interaction (SMSI) or weak metal support interaction (WMSI) reported in the literature] [61-63]. Therefore, $5 \% \mathrm{Pd} / \mathrm{TiO}_{2}$ (Cat. $\mathrm{D}$, anatase-type) indicated efficient catalyst activity toward the Suzuki-Miyaura coupling reaction, while $\mathrm{TiO}_{2}$ possessed only a small specific surface area (from $110 \mathrm{~m}^{2} \mathrm{~g}^{-1}$ of the fresh catalyst to $22 \mathrm{~m}^{2} \mathrm{~g}^{-1}$ ).
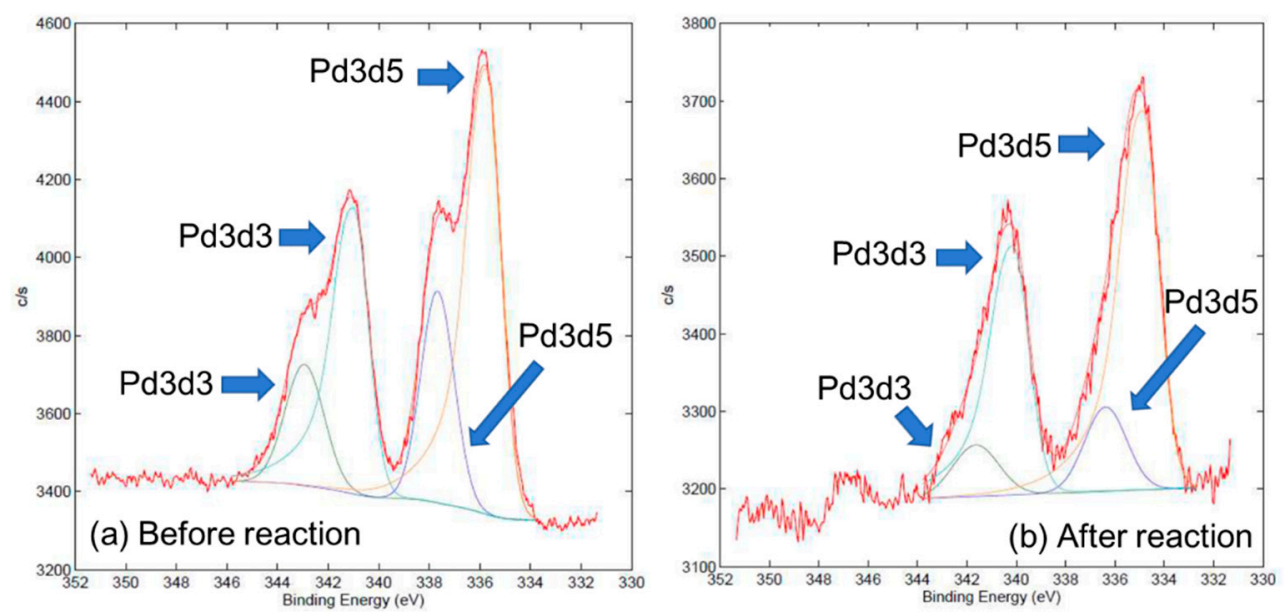

Figure 2. XPS spectra of $5 \% \mathrm{Pd} / \mathrm{TiO}_{2}$ (Cat. D, anatase-type) before (a) and after (b) the Suzuki-Miyaura coupling reaction. 
The average palladium particle sizes on $5 \% \mathrm{Pd} / \mathrm{TiO}_{2}$ (Cat. $\mathrm{D}$, anatase-type) before and after the Suzuki-Miyaura coupling reaction (Figure $3 a$ and $3 b$ ) were each roughly estimated to be 1 to 2 and 3 to $4 \mathrm{~nm}$ based on TEM images. These results strongly suggested that the high catalyst activity of fresh $5 \% \mathrm{Pd} / \mathrm{TiO}_{2}$ (Cat. D, anatase-type) might be induced by the extensively distributed small $\mathrm{Pd}$ nanoparticles (Figure 3a) while the gradual increase of the Pd particle size during the Suzuki-Miyaura coupling reaction probably caused the decreasing of catalytic activity [Figure $3 \mathrm{~b}$ and Equation (2)].

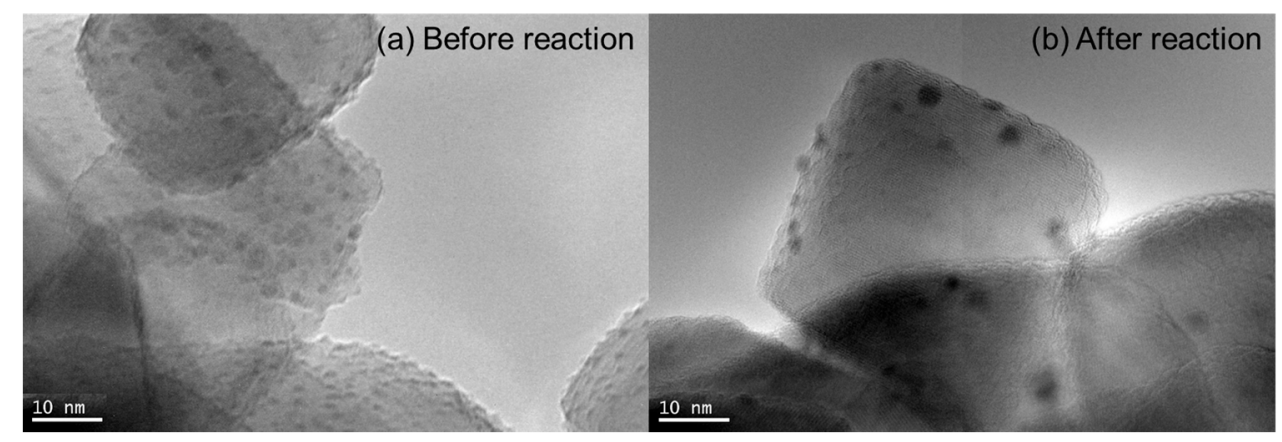

Figure 3. Transmission electron microscopy (TEM) images of $5 \% \mathrm{Pd} / \mathrm{TiO}_{2}$ (Cat. $\mathbf{D}$, anatase-type) before (a) and after (b) the Suzuki-Miyaura coupling reaction.

Furthermore, the chemisorption behavior of carbon monoxide on $5 \% \mathrm{Pd} / \mathrm{TiO}_{2}$ (Cat. $\mathbf{D}$, anatase-type) indicated the significant degradation of the specific surface area from $110 \mathrm{~m}^{2} \mathrm{~g}^{-1}$ of the fresh catalyst to $22 \mathrm{~m}^{2} \mathrm{~g}^{-1}$ after the Suzuki-Miyaura coupling reaction due to the remarkable Pd sintering. Based on these experimental and analytical investigations, the decreasing of catalytic activity of the recovered $5 \%$ $\mathrm{Pd} / \mathrm{TiO}_{2}$ (Cat. $\mathbf{D}$, anatase-type) should be caused by the deterioration of the specific surface area due to the $\mathrm{Pd}$ sintering. Therefore, $5 \% \mathrm{Pd} / \mathrm{TiO}_{2}$ (Cat. $\mathrm{D}$, anatase-type) was unfortunately hard to reuse, while the fresh catalyst was suitable for the ligand-free Suzuki-Miyaura coupling reaction of aryl chlorides.

\section{Materials and Methods}

\subsection{General}

All reagents and solvents were obtained from commercial sources and used without further purification. $\mathrm{Pd}(\mathrm{OAc})_{2}$ was obtained from N.E. Chemcat Co. (Tokyo, Japan). The ${ }^{1} \mathrm{H}$ NMR and ${ }^{13} \mathrm{C}$ NMR spectra were recorded on a JEOL ECZ-400 (400 MHz for ${ }^{1} \mathrm{H}$ NMR and $100 \mathrm{MHz}$ for ${ }^{13} \mathrm{C}$ NMR) spectrometer. $\mathrm{CDCl}_{3}$ was used as the solvent for NMR measurement. Chemical shifts (d) are expressed in part per million and internally referenced $\left(0.00 \mathrm{ppm}\right.$ for tetramethylsilane or $7.26 \mathrm{ppm}$ for $\mathrm{CHCl}_{3}$ for ${ }^{1} \mathrm{H}$ NMR for $\mathrm{CDCl}_{3}$ and $77.0 \mathrm{ppm}$ for $\mathrm{CDCl}_{3}$ for ${ }^{13} \mathrm{C}$ NMR). SHIMADZU AA-7000 was used for the atomic absorption spectrometry (AAS). All of ${ }^{1} \mathrm{H}$ and ${ }^{13} \mathrm{C}$ NMR spectra of known products were identical with those in the literature.

\subsection{Experimentals}

\subsubsection{Preparation of $5 \% \mathrm{Pd} / \mathrm{TiO}_{2}$ (Cat. $\mathbf{D}$, anatase-type)}

A suspension of anatase-type $\mathrm{TiO}_{2}(3.00 \mathrm{~g}$, colorless powder) in $\mathrm{MeCN}$ solution $(30 \mathrm{~mL})$ of $\mathrm{Pd}(\mathrm{OAc})_{2}[316 \mathrm{mg}, 1.41 \mathrm{mmol}(150 \mathrm{mg}$, palladium quantity)] was stirred under argon atmosphere at $25{ }^{\circ} \mathrm{C}$ for 4 days. The resulting light yellow solid was collected by filtration $(1 \mu \mathrm{m}$ filter paper), washed with $\mathrm{H}_{2} \mathrm{O}(5 \mathrm{~mL} \times 5)$ and EtOAc $(5 \mathrm{~mL} \times 5)$ and dried in vacuo for $24 \mathrm{~h}$ to afford the $\mathrm{Pd} / \mathrm{TiO}_{2}$ ( $3.15 \mathrm{~g}$, Cat. D, anatase-type). The filtrate was concentrated in vacuo, and then transferred to a $100 \mathrm{~mL}$ volumetric flask with $\mathrm{H}_{2} \mathrm{O}$ and $15.58 \mathrm{ppm}$ (1.56 mg) of palladium species were observed in the diluted filtrate by atomic absorption spectrometry (SHIMADZU AA-7000, Kyoto, Japan). Since the total 
palladium species which was not absorbed on anatase-type $\mathrm{TiO}_{2}$ was $1.56 \mathrm{mg}$, the palladium content of the anatase-type $\mathrm{Pd} / \mathrm{TiO}_{2}$ (Cat. D) was approximately $5 \%(4.7 \%)[(150-1.56) / 3150 \times 100]$.

\subsubsection{Preparation of $5 \% \mathrm{Pd}(\mathrm{red}) / \mathrm{TiO}_{2}$ (Cat. A, Anatase-Type)}

The collected anatase-type $5 \% \mathrm{Pd} / \mathrm{TiO}_{2}$ (Cat. D, $500.0 \mathrm{mg}$ ) was stirred with $\mathrm{NH}_{2} \mathrm{NH}_{2} \cdot \mathrm{H}_{2} \mathrm{O}(29.2 \mu \mathrm{L}$, $0.6 \mathrm{mmol})$ in $\mathrm{H}_{2} \mathrm{O}(40 \mathrm{~mL})$ under argon atmosphere at $25^{\circ} \mathrm{C}$ for $24 \mathrm{~h}$. The grayish white solid was collected by filtration $\left(1 \mu \mathrm{m}\right.$ filter paper), washed with $\mathrm{H}_{2} \mathrm{O}(10 \mathrm{~mL} \times 5)$ and EtOAc $(10 \mathrm{~mL} \times 5)$ and dried in vacuo for $12 \mathrm{~h}$ to give $5 \% \mathrm{Pd}(\mathrm{red}) / \mathrm{TiO}_{2}$ (343 mg, Cat. A, anatase-type).

\subsubsection{Typical Procedure for the Coupling Reaction between Aryl Chlorides and Arylboronic Acids}

A mixture of $5 \% \mathrm{Pd} / \mathrm{TiO}_{2}(30.0 \mathrm{mg}, 12.5 \mu \mathrm{mol})$, an aryl chloride $(250 \mu \mathrm{mol})$, an arylboronic acid (375 $\mu \mathrm{mol})$ and $\mathrm{Cs}_{2} \mathrm{CO}_{3}(163 \mathrm{mg}, 500 \mu \mathrm{mol})$ in DMA $(1 \mathrm{~mL})$ was stirred at $80^{\circ} \mathrm{C}$ in a test tube tightly sealed under argon atmosphere. After $24 \mathrm{~h}$, the mixture was cooled to $25^{\circ} \mathrm{C}$, diluted with EtOAc $(10 \mathrm{~mL})$ and $\mathrm{H}_{2} \mathrm{O}(10 \mathrm{~mL})$, and filtered through a membrane filter (pore size: $\left.0.2 \mu \mathrm{m}\right)$. The catalyst on the filter was washed with EtOAc $(10 \mathrm{~mL})$ and $\mathrm{H}_{2} \mathrm{O}(10 \mathrm{~mL})$, and combined filtrates were separated to two layers. The aqueous layer was extracted with EtOAc $(15 \mathrm{~mL} \times 3)$, and combined EtOAc layers were washed with $\mathrm{H}_{2} \mathrm{O}(20 \mathrm{~mL} \times 3)$ and brine $(20 \mathrm{~mL})$, dried over $\mathrm{Na}_{2} \mathrm{SO}_{4}$, filtered, and concentrated in vacuo. The residue was purified by silica-gel column chromatography using hexane/EtOAc (10:1) as eluents to afford the corresponding biaryl derivative.

\subsubsection{Procedure for Reuse Test of Recovered $5 \% \mathrm{Pd} / \mathrm{TiO}_{2}$ (Cat. D, anatase-type) (Equation (2))}

Three exactly the same reaction mixtures containing $5 \% \mathrm{Pd} / \mathrm{TiO}_{2}$ (Cat. D, anatase-type) $(30.0 \mathrm{mg}$, $12.5 \mu \mathrm{mol}), 4^{\prime}$-chloroacetophenone (1a, $\left.38.6 \mathrm{mg}, 250 \mu \mathrm{mol}\right)$, a phenylboronic acid (2a, $\left.45.7 \mathrm{mg}, 375 \mu \mathrm{mol}\right)$, $\mathrm{Cs}_{2} \mathrm{CO}_{3}(163 \mathrm{mg}, 500 \mu \mathrm{mol})$ in DMA $(1 \mathrm{~mL})$ were stirred at $80^{\circ} \mathrm{C}$ in each separate sealed test tube under argon atmosphere. After $24 \mathrm{~h}$, the combined reaction mixture was filtered using a funnel $(1 \mu \mathrm{m}$ filter paper). The catalyst on the filter was washed with EtOAc $(3 \mathrm{~mL} \times 5)$, and the recovered catalyst was dried at room temperature under reduced pressure overnight, then weighed $(90.0 \mathrm{mg}, 100 \%)$. The reaction of the second run was carried out in the same manner as the first run except for using the recovered $5 \% \mathrm{Pd} / \mathrm{TiO}_{2}(30.0 \mathrm{mg}, 12.5 \mu \mathrm{mol})$ and only one reaction mixture in a test tube. The ${ }^{1} \mathrm{H} \mathrm{NMR}$ ratio of 1a and 3a indicated 37:63.

3.2.5. Procedure for the Confirmation Experiment of Pd Leaching in the Reaction Medium and Pd Contamination of the Coupling Product after Purification Processes (Equatiopn (3))

A mixture of $5 \% \mathrm{Pd} / \mathrm{TiO}_{2}$ (Cat. D, anatase-type) $(150.0 \mathrm{mg}, 62.5 \mu \mathrm{mol}), 4^{\prime}$-Chloroacetophenone (1a, $193.0 \mathrm{mg}, 1.25 \mathrm{mmol})$, a phenylboronic acid (2a, $229.1 \mathrm{mg}, 1.88 \mathrm{mmol})$ and $\mathrm{Cs}_{2} \mathrm{CO}_{3}(815 \mathrm{mg}$, $2.5 \mathrm{mmol})$ in DMA $(5 \mathrm{~mL})$ was stirred at $80^{\circ} \mathrm{C}$ in a test tube sealed under argon. After $24 \mathrm{~h}$, the mixture was filtered using a funnel ( $1 \mu \mathrm{m}$ filter paper). The catalyst on the filter paper was washed with EtOAc $(15 \mathrm{~mL} \times 5)$. The filtrate was concentrated in vacuo and transferred to a $100 \mathrm{~mL}$ volumetric flask with EtOAc. No palladium species were observed $[0.0 \mathrm{ppm}(0.0 \mathrm{mg})]$ in the diluted filtrate by measurement of atomic absorption spectrometry (SHIMADZU AA-7000). The organic layer was washed with $\mathrm{H}_{2} \mathrm{O}$ $(20 \mathrm{~mL} \times 3)$ and brine $(20 \mathrm{~mL})$, dried over $\mathrm{Na}_{2} \mathrm{SO}_{4}$, filtered and concentrated in vacuo. The residue was purified by silica-gel column chromatography using hexane/EtOAc (10:1) as eluents to afford the corresponding analytically pure 4-acetylbiphenyl (3a). The obtained $3 \mathbf{a}$ was transferred to a $100 \mathrm{~mL}$ volumetric flask with EtOAc, and no palladium species were observed $[0.0 \mathrm{ppm}(0.0 \mathrm{mg})]$ in the diluted filtrate by measurement of atomic absorption spectrometry.

\section{Conclusions}

We have prepared $\mathrm{TiO}_{2}$-supported catalysts possessing different crystalline structure of $\mathrm{TiO}_{2}$-and evaluated the significant effect based on the crystalline types on the ligand-free Suzuki-Miyaura cross coupling reaction mainly of aryl chlorides for the first time. The anatase-type $\mathrm{TiO}_{2}$ supported $\mathrm{Pd}$ 
catalyst $\left[\mathrm{Pd} / \mathrm{TiO}_{2}\right.$ (Cat. D, anatase-type)] demonstrated efficient catalyst activity toward the ligand-free Suzuki-Miyaura cross coupling reaction of aryl chlorides. The quite high catalyst activity would be due to the extensively distributed small $\mathrm{Pd}$ nanoparticles on the anatase-type $\mathrm{TiO}_{2}$ and the appropriate interaction between the $\mathrm{Pd}$ species and anatase-type $\mathrm{TiO}_{2}$ based on the reduction of the $\mathrm{Pd}(\mathrm{II})$ to $\mathrm{Pd}(0)$ species, although details of the actual electron donating process have not been clarified. Various aryl chlorides possessing electron withdrawing substituents, such as acetyl and ester functionalities, on the aromatic ring were smoothly coupled with aryl and heteroarylboronic acids in moderate to excellent yields. For aryl halides possessing an electron donating substrate on the aromatic ring, the coupling reaction could be performed using the corresponding aryl bromide.

Supplementary Materials: The following are available online at http://www.mdpi.com/2073-4344/9/5/461/s1, Figure S1. XPS image and curve-fitting of Pd peaks (Cat. D-I). Figure S2. XPS image and curve-fitting of the $\mathrm{Pd}$ peaks of $5 \% \mathrm{Pd} / \mathrm{TiO}_{2}$ (Cat. D, anatase-type) before and after use. Table S1. Base efficiency. Table S2. Solvent efficiency. Table S3. Time course study.

Author Contributions: Writing—original draft preparation T.Y.; designing the research, T.Y., T.I., K.P., Y.S. and H.S.; investigation and analysis, H.M., T.T., M.Y., N.I., Y.O. and Y.T.; project administration, supervision and polishing up the manuscript, H.S.

Funding: This research received no external funding.

Acknowledgments: We sincerely appreciate the N.E. Chemcat Co. for providing the $\mathrm{Pd}(\mathrm{OAc})_{2}$.

Conflicts of Interest: The authors declare no conflict of interest.

\section{References}

1. Miyaura, N.; Suzuki, A. Palladium-Catalyzed Cross-Coupling Reactions of Organoboron Compounds. Chem. Rev. 1995, 95, 2457-2483. [CrossRef]

2. Hassan, J.; Sèvignon, M.; Gozzi, C.; Schulz, E.; Lemaire, M. Aryl-Aryl Bond Formation One Century after the Discovery of the Ullmann Reaction. Chem. Rev. 2002, 102, 1359-1470. [PubMed]

3. Ackermann, L. Modern Arylation Methods; Wiley: Weinheim, Germany, 2009.

4. Bringmann, G.; Gulder, T.; Gulder, T.A.M.; Breuning, M. Atroposelective Total Synthesis of Axially Chiral Biaryl Natural Products. Chem. Rev. 2011, 111, 563-639. [CrossRef]

5. Wu, J.-S.; Cheng, S.-W.; Cheng, Y.-J.; Hsu, C.-S. Donor-acceptor conjugated polymers based on multifused ladder-type arenes for organic solar cells. Chem. Soc. Rev. 2015, 44, 1113-1154. [CrossRef] [PubMed]

6. Yang, Y.; Lan, J.; You, J. Oxidative C-H/C-H Coupling Reactions between Two (Hetero)arenes. Chem. Rev. 2017, 117, 8787-8863. [CrossRef] [PubMed]

7. Yin, L.; Liebscher, J. Carbon-Carbon Coupling Reactions Catalyzed by Heterogeneous Palladium Catalysts. Chem. Rev. 2007, 107, 133-173. [CrossRef] [PubMed]

8. Fihri, A.; Bouhrara, M.; Nekoueishahraki, B.; Basset, J.-M.; Polshettiwar, V. Nanocatalysts for Suzuki cross-coupling reactions. Chem. Soc. Rev. 2011, 40, 5181-5203. [CrossRef]

9. Monguchi, Y.; Fujita, Y.; Hashimoto, S.; Ina, M.; Takahashi, T.; Ito, R.; Nozaki, K.; Maegawa, T.; Sajiki, H. Palladium on carbon-catalyzed solvent-free and solid-phase hydrogenation and Suzuki-Miyaura reaction. Tetrahedron 2011, 67, 8628-8634.

10. Kitamura, Y.; Sako, S.; Udzu, T.; Tsutsui, A.; Maegawa, T.; Monguchi, Y.; Sajiki, H. Ligand-free Pd/C-catalyzed Suzuki-Miyaura coupling reaction for the synthesis of heterobiaryl derivatives. Chem. Commun. 2007, 5069-5071. [CrossRef] [PubMed]

11. Maegawa, T.; Kitamura, Y.; Sako, S.; Udzu, T.; Sakurai, A.; Tanaka, A.; Kobayashi, Y.; Endo, K.; Bora, U.; Kurita, T.; et al. Heterogeneous Pd/C-Catalyzed Ligand-Free, Room-Temperature Suzuki-Miyaura Coupling Reactions in Aqueous Media. Chem. Eur. J. 2007, 13, 5937-5943. [CrossRef] [PubMed]

12. Kitamura, Y.; Sakurai, A.; Udzu, T.; Maegawa, T.; Monguchi, Y.; Sajiki, H. Heterogeneous Pd/C-catalyzed ligand-free Suzuki-Miyaura coupling reaction using aryl boronic esters. Tetrahedron 2007, 6, 10596-10602. [CrossRef]

13. Shokouhimehr, M.; Asl, M.S.; Mazinani, B. Modulated large-pore mesoporous silica as an efficient base catalyst for the Henry reaction. Res. Chem. Intermed. 2018, 44, 1617-1626. [CrossRef] 
14. Shokouhimehr, M. Magnetically Separable and Sustainable Nanostructured Catalysts for Heterogeneous Reduction of Nitroaromatics. Catalysts 2015, 5, 534-560. [CrossRef]

15. Zhang, K.; Hong, K.; Suh, J.M.; Lee, T.H.; Kwon, O.; Shokouhimehr, M.; Jang, H.W. Facile synthesis of monodispersed Pd nanocatalysts decorated on graphene oxide for reduction of nitroaromatics in aqueous solution. Res. Chem. Intermediat. 2019, 45, 599-611. [CrossRef]

16. Shokouhimehr, M.; Hong, K.; Lee, T.H.; Moon, C.W.; Hong, S.P.; Zhang, K.; Suh, J.M.; Choi, K.S.; Varma, R.S.; Jang, H.W. Magnetically retrievable nanocomposite adorned with Pd nanocatalysts: Efficient reduction of nitroaromatics in aqueous media. Green Chem. 2018, 20, 3809-3817. [CrossRef]

17. Choi, K.-H.; Shokouhimehr, M.; Sung, Y.-E. Heterogeneous Suzuki Cross-Coupling Reaction Catalyzed by Magnetically Recyclable Nanocatalyst. Bull. Korean Chem. Soc. 2013, 34, 1477-1480. [CrossRef]

18. Kim, A.; Rafiaei, S.M.; Abolhosseini, S.; Shokouhimehr, M. Palladium Nanocatalysts Confined in Mesoporous Silica for Heterogeneous Reduction of Nitroaromatics. Energy Environ. Focus 2015, 4, 18-23. [CrossRef]

19. Shokouhimehr, M.; Lee, J.E.; Han, S.I.; Hyeon, T. Magnetically recyclable hollow nanocomposite catalysts for heterogeneous reduction of nitroarenes and Suzuki reactions. Chem. Commun. 2013, 49, 4779-4781. [CrossRef]

20. Shokouhimehr, M.; Kim, T.; Jun, S.W.; Shin, K.; Jang, Y.; Kim, B.H.; Kim, J.; Hyeon, T. Magnetically separable carbon nanocomposite catalysts for efficient nitroarene reduction and Suzuki reactions. Appl. Catal. A General 2014, 476, 133-139. [CrossRef]

21. Li, G.; Yang, H.; Li, W.; Zhang, G. Rationally designed palladium complexes on a bulky N-heterocyclic carbene-functionalized organosilica: An efficient solid catalyst for the Suzuki-Miyaura coupling of challenging aryl chlorides. Green Chem. 2011, 13, 2939-2947. [CrossRef]

22. Karimi, B.; Akhavan, P.F. A Study on Applications of N-Substituted Main-Chain NHC-Palladium Polymers as Recyclable Self-Supported Catalysts for the Suzuki-Miyaura Coupling of Aryl Chlorides in Water. Inorg. Chem. 2011, 50, 6063-6072. [CrossRef]

23. Das, P.; Sharma, D.; Shil, A.K.; Kumari, A. Solid-supported palladium nano and microparticles: An efficient heterogeneous catalyst for ligand-free Suzuki-Miyaura cross coupling reaction. Tetrahedron Lett. 2011, 52, 1176-1178. [CrossRef]

24. Yamada, Y.M.A.; Sarkar, S.M.; Uozumi, Y. Self-Assembled Poly(imidazole-palladium): Highly Active, Reusable Catalyst at Parts per Million to Parts per Billion Levels. J. Am. Chem. Soc. 2012, 134, 3190-3198. [CrossRef]

25. Wu, L.; Li, B.-O.; Huang, Y.-Y.; Zhou, H.-F.; He, Y.-M.; Fan, Q.-H. Phosphine Dendrimer-Stabilized Palladium Nanoparticles, a Highly Active and Recyclable Catalyst for the Suzuki-Miyaura Reaction and Hydrogenation. Org. Lett. 2006, 8, 3605-3608. [CrossRef] [PubMed]

26. Schweizer, S.; Becht, J.-M.; Drian, C.L. Highly Efficient and Reusable Supported Pd Catalysts for Suzuki-Miyaura Reactions of Aryl Chlorides. Org. Lett. 2007, 9, 3777-3780. [CrossRef] [PubMed]

27. Sayah, R.; Glegoła, K.; Framery, E.; Dufaud, V. Suzuki-Miyaura Reactions of Aryl Chloride Derivatives with Arylboronic Acids using Mesoporous Silica-Supported Aryldicyclohexylphosphine. Adv. Synth. Catal. 2007, 349, 373-381. [CrossRef]

28. Pandarus, V.; Desplantier-Giscard, D.; Gingras, G.; Béland, F.; Ciriminna, R.; Pagliaro, M. Greening the Valsartan Synthesis: Scale-up of Key Suzuki-Miyaura Coupling over SiliaCat DPP-Pd. Org. Process Res. Dev. 2013, 17, 1492-1497. [CrossRef]

29. Lee, D.-H.; Choi, M.; Yu, B.-W.; Ryoo, R.; Taher, A.; Hossain, S.; Jin, M.-J. Expanded Heterogeneous Suzuki-Miyaura Coupling Reactions of Aryl and Heteroaryl Chlorides under Mild Conditions. Adv. Synth. Catal. 2009, 351, 2912-2920. [CrossRef]

30. Jin, M.-J.; Lee, D.-H. A Practical Heterogeneous Catalyst for the Suzuki, Sonogashira, and Stille Coupling Reactions of Unreactive Aryl Chlorides. Angew. Chem. Int. Ed. 2010, 49, 1119-1122. [CrossRef]

31. LeBlond, C.R.; Andrews, A.T.; Sun, Y.; Sowa, J.R., Jr. Activation of Aryl Chlorides for Suzuki Cross-Coupling by Ligandless, Heterogeneous Palladium. Org. Lett. 2001, 3, 1555-1557. [CrossRef]

32. Tagata, T.; Nishida, M. Palladium Charcoal-Catalyzed Suzuki-Miyaura Coupling to Obtain Arylpyridines and Arylquinolines. J. Org. Chem. 2003, 68, 9412-9415. [CrossRef] [PubMed]

33. Arvela, R.K.; Leadbeater, N.E. Suzuki Coupling of Aryl Chlorides with Phenylboronic Acid in Water, Using Microwave Heating with Simultaneous Cooling. Org. Lett. 2005, 7, 2101-2104. [CrossRef] [PubMed] 
34. Ohtaka, A.; Sakaguchi, E.; Yamaguchi, T.; Hanasaka, G.; Uozumi, Y.; Shimomura, O.; Nomura, R. A Recyclable "Boomerang" Linear Polystyrene-Stabilized Pd Nanoparticles for the Suzuki Coupling Reaction of Aryl Chlorides in Water. Chem CatChem 2013, 5, 2167-2169. [CrossRef]

35. Yuan, B.; Pan, Y.; Li, Y.; Yin, B.; Jiang, H.A. Highly Active Heterogeneous Palladium Catalyst for the Suzuki-Miyaura and Ullmann Coupling Reactions of Aryl Chlorides in Aqueous Media. Angew. Chem. Int. Ed. 2010, 49, 4054-4058. [CrossRef] [PubMed]

36. Kogan, V.; Aizenshtat, Z.; Popovitz-Biro, R.; Newmann, R. Carbon-Carbon and Carbon-Nitrogen Coupling Reactions Catalyzed by Palladium Nanoparticles Derived from a Palladium Substituted Keggin-Type Polyoxometalate. Org. Lett. 2002, 4, 3529-3532. [CrossRef] [PubMed]

37. Choudary, B.M.; Madhi, S.; Chowdari, N.S.; Kantam, M.L.; Sreedhar, B. Layered Double Hydroxide Supported Nanopalladium Catalyst for Heck-, Suzuki-, Sonogashira-, and Stille-Type Coupling Reactions of Chloroarenes. J. Am. Chem. Soc. 2002, 124, 14127-14136. [CrossRef] [PubMed]

38. Ciriminna, R.; Pandarus, V.; Gingras, G.; Béland, F.; Demma, P.; Pagliaro, M. Heterogeneously catalyzed Suzuki-Miyaura conversion of broad scope. RSC Adv. 2012, 2, 10798-10804. [CrossRef]

39. Monguchi, Y.; Ichikawa, T.; Netsu, M.; Hattori, T.; Mizusaki, T.; Sawama, Y.; Sajiki, H. Tertiary-AminoFunctionalized Resin-Supported Palladium Catalyst for the Heterogeneous Suzuki-Miyaura Reaction of Aryl Chlorides. Synlett 2015, 26, 2014-2018. [CrossRef]

40. Ichikawa, T.; Netsu, M.; Mizuno, M.; Mizusaki, T.; Takagi, Y.; Sawama, Y.; Monguchi, Y.; Sajiki, H. Development of a Unique Heterogeneous Palladium Catalyst for the Suzuki-Miyaura Reaction using (Hetero)aryl Chlorides and Chemoselective Hydrogenation. Adv. Synth. Catal. 2017, 359, 2269-2279. [CrossRef]

41. Ichikawa, T.; Mizuno, M.; Ueda, S.; Ohneda, N.; Odajima, H.; Sawama, Y.; Monguchi, Y.; Sajiki, H. A practical method for heterogeneously-catalyzed Mizoroki-Heck reaction: Flow system with adjustment of microwave resonance as an energy source. Tetrahedron 2018, 74, 1810-1816. [CrossRef]

42. Sreedhar, B.; Yada, D.; Reddy, P.S. Nanocrystalline Titania-Supported Palladium(0) Nanoparticles for Suzuki-Miyaura Cross-Coupling of Aryl and Heteroaryl Halides. Adv. Synth. Catal. 2011, 353, 2823-2836. [CrossRef]

43. Nasrollahzadeh, M.; Sajadi, S.M. Green synthesis, characterization and catalytic activity of the $\mathrm{Pd} / \mathrm{TiO} \mathrm{O}_{2}$ nanoparticles for the ligand-free Suzuki-Miyaura coupling reaction. J. Colloid Interf. Sci. 2016, 465, 121-127. [CrossRef]

44. Mondal, P.; Khatun, R.; Bhanja, P.; Bhaumik, A.; Das, D.; Islam, S.M. Palladium nanoparticles embedded on mesoporous $\mathrm{TiO}_{2}$ material $\left(\mathrm{Pd} @ \mathrm{MTiO}_{2}\right)$ as an efficient heterogeneous catalyst for Suzuki-Coupling reactions in water medium. J. Colloid Interf. Sci. 2017, 508, 378-386. [CrossRef] [PubMed]

45. Liu, B.; Niu, Y.; Li, Y.; Yang, F.; Guo, J.; Wang, Q.; Jing, P.; Zhang, J.; Yun, G. A mesoporous "shell-in-shell” structured nanocatalyst with large surface area, enhanced synergy, and improved catalytic performance for Suzuki-Miyaura coupling reaction. Chem. Commun. 2014, 50, 12356-12359. [CrossRef]

46. Kamari, Y.; Ghiaci, M. Incorporation of $\mathrm{TiO}_{2}$ coating on a palladium heterogeneous nanocatalyst. A new method to improve reusability of a catalyst. Catal. Commun. 2016, 84, 16-20. [CrossRef]

47. Koohgard, M.; Hosseini-Sarvari, M. Enhancement of Suzuki-Miyaura coupling reaction by photocatalytic palladium nanoparticles anchored to $\mathrm{TiO}_{2}$ under visible light irradiation. Catal. Commun. 2018, 111, 10-15. [CrossRef]

48. Shiraishi, Y.; Takeda, Y.; Sugano, Y.; Ichikawa, S.; Tanaka, S.; Hirai, T. Highly efficient photocatalytic dehalogenation of organic halides on $\mathrm{TiO}_{2}$ loaded with bimetallic Pd-Pt alloy nanoparticles. Chem. Commun. 2011, 47, 7863-7865. [CrossRef]

49. Yoshida, H.; Fujimura, Y.; Yuzawa, H.; Kumagai, J.; Yoshida, M. A heterogeneous palladium catalyst hybridised with a titanium dioxide photocatalyst for direct $\mathrm{C}-\mathrm{C}$ bond formation between an aromatic ring and acetonitrile. Chem. Commun. 2013, 49, 3793-3795. [CrossRef] [PubMed]

50. Sikhwivhilu, L.M.; Coville, N.J.; Naresh, D.; Chary, K.V.R.; Vishwanathan, V. Nanotubular titanate supported palladium catalysts: The influence of structure and morphology on phenol hydrogenation activity. Appl. Catal. A General 2007, 324, 52-61. [CrossRef]

51. Yang, J.; Cao, L.-X.; Wang, G.-C. Acetylene hydrogenation on anatase $\mathrm{TiO}_{2}(101)$ supported $\mathrm{Pd}_{4}$ cluster: Oxygen deficiency effect. J. Mol. Model. 2012, 18, 3329-3339. [CrossRef] [PubMed] 
52. Ortel, E.; Sokolov, S.; Zielke, C.; Lauermann, I.; Selve, S.; Weh, K.; Paul, B.; Polte, J.; Kraehnert, R. Supported Mesoporous and Hierarchical Porous $\mathrm{Pd} / \mathrm{TiO}_{2}$ Catalytic Coatings with Controlled Particle Size and Pore Structure. Chem. Mater. 2012, 24, 3828-3838. [CrossRef]

53. Khatun, R.; Bhanja, P.; Mondal, P.; Bhaumik, A.; Das, D.; Islam, S.M. Palladium nanoparticles embedded over mesoporous $\mathrm{TiO}_{2}$ for chemical fixation of $\mathrm{CO}_{2}$ under atmospheric pressure and solvent-free conditions. New J. Chem. 2017, 41, 12937-12946. [CrossRef]

54. Melchionna, M.; Beltram, A.; Montini, T.; Monai, M.; Nasi, L.; Fornasiero, P.; Prato, M. Highly efficient hydrogen production through ethanol photoreforming by a carbon nanocone/ $\mathrm{Pd} @ \mathrm{TiO}_{2}$ hybrid catalyst. Chem. Commun. 2016, 52, 764-767. [CrossRef] [PubMed]

55. Sayed, F.N.; Jayakumar, O.D.; Sasikala, R.; Kadam, R.M.; Bharadwaj, S.R.; Kienle, L.; Schürmann, U.; Kaps, S.; Adelung, R.; Mittal, J.P.; Tyagi, A.K. Photochemical Hydrogen Generation Using Nitrogen-Doped $\mathrm{TiO}_{2}-\mathrm{Pd}$ Nanoparticles: Facile Synthesis and Effect of $\mathrm{Ti}^{3+}$ Incorporation. J. Phys. Chem. C 2012, 116, 12462-12467. [CrossRef]

56. Bahruji, H.; Bowkera, M.; Brookes, C.; Davies, P.R.; Wawata, I. The adsorption and reaction of alcohols on $\mathrm{TiO}_{2}$ and $\mathrm{Pd} / \mathrm{TiO}_{2}$ catalysts. Appl. Catal. A General 2013, 454, 66-73. [CrossRef]

57. Cao, C.; Yan, Y.; Yu, Y.; Yang, X.; Liu, W.; Cao, Y. Modification of Pd and Mn on the Surface of TiO 2 with Enhanced Photocatalytic Activity for Photoreduction of $\mathrm{CO}_{2}$ into $\mathrm{CH}_{4}$. J. Phys. Chem. C 2017, 121, $270-277$. [CrossRef]

58. Sayed, F.N.; Sasikala, R.; Jayakumar, O.D.; Rao, R.; Betty, C.A.; Chokkalingam, A.; Kadam, R.M.; Jagannath; Bharadwaj, S.R.; Vinuc, A.; Tyagi, A.K. Photocatalytic hydrogen generation from water using a hybrid of graphene nanoplatelets and self doped $\mathrm{TiO}_{2}-\mathrm{Pd}$. RSC Adv. 2014, 4, 13469-13476. [CrossRef]

59. Nasrollahzadeh, M.; Azarian, A.; Ehsani, A.; Khalaj, M. Preparation, optical properties and catalytic activity of $\mathrm{TiO}_{2} @ \mathrm{Pd}$ nanoparticles as heterogeneous and reusable catalysts for ligand-free Heck coupling reaction. J. Mol. Catal. A Chem. 2014, 394, 205-210. [CrossRef]

60. Dodson, J.J.; Hagelin-Weaver, H.E. Effect of titania structure on palladium oxide catalysts in the oxidativecoupling of 4-methylpyridine. J. Mol. Catal. A Chem. 2015, 410, 271-279. [CrossRef]

61. Sá, J.; Bernardi, J.; Anderson, J.A. Imaging of low temperature induced SMSI on $\mathrm{Pd} / \mathrm{TiO}_{2}$ catalysts. Catal. Lett. 2007, 114, 91-95. [CrossRef]

62. Colmenares, J.C.; Magdziarz, A.; Aramendia, M.A.; Marinas, A.; Marinas, J.M.; Urbano, F.J.; Navio, J.A. Influence of the strong metal support interaction effect (SMSI) of $\mathrm{Pt} / \mathrm{TiO}_{2}$ and $\mathrm{Pd} / \mathrm{TiO}_{2}$ systems in the photocatalytic biohydrogen production from glucose solution. Catal. Commun. 2011, 16, 1-6. [CrossRef]

63. Pan, C.-J.; Tsai, M.-C.; Su, W.-N.; Rick, J.; Akalework, N.G.; Agegnehu, A.K.; Cheng, S.-Y.; Hwang, B.-J. Tuning/exploiting Strong Metal-Support Interaction (SMSI) in Heterogeneous Catalysis. J. Taiwan Inst. Chem. E 2017, 74, 154-186. [CrossRef]

64. O’Brien, C.J.; Kantchev, E.A.B.; Valente, C.; Hadei, N.; Chass, G.A.; Lough, A.; Hopkinson, A.C.; Organ, M.G. Easily Prepared Air-and Moisture-Stable Pd-NHC (NHC=N-Heterocyclic Carbene) Complexes: A Reliable, User-Friendly, Highly Active Palladium Precatalyst for the Suzuki-Miyaura Reaction. Chem. Eur. J. 2006, 12, 4743-4748. [CrossRef]

65. Valente, C.; Çalimsiz, S.; Hoi, K.H.; Mallik, D.; Sayah, M.; Organ, M.G. The Development of Bulky Palladium NHC Complexes for the Most-Challenging Cross-Coupling Reactions. Angew. Chem. Int. Ed. 2012, 51, 3314-3332. [CrossRef] [PubMed]

66. Petrassi, H.M.; Johnson, S.M.; Purkey, H.E.; Chiang, K.P.; Walkup, T.; Jiang, X.; Powers, E.T.; Kelly, J.W. Potent and Selective Structure-Based Dibenzofuran Inhibitors of Transthyretin Amyloidogenesis: Kinetic Stabilization of the Native State. J. Am. Chem. Soc. 2005, 127, 6662-6671. [CrossRef]

67. Oliveira, A.M.A.G.; Raposo, M.M.M.; Oliveira-Campos, A.M.F.; Machado, A.E.H.; Puapairoj, P.; Pedro, M.; Nascimento, M.S.J.; Portela, C.; Afonso, C.; Pinto, M. Psoralen analogues: Synthesis, inhibitory activity of growth of human tumor cell lines and computational studies. Eur. J. Med. Chem. 2006, 41, 367-372. [CrossRef] [PubMed]

68. Lusic, H.; Uprety, R.; Deiters, A. Improved Synthesis of the Two-Photon Caging Group 3-Nitro-2-Ethyldibenzofuran and Its Application to a Caged Thymidine Phosphoramidite. Org. Lett. 2010, 12, 916-919. [CrossRef] [PubMed]

69. Love, B.E. Isolation and synthesis of polyoxygenated dibenzofurans possessing biological activity. Eur. J. Med. Chem. 2015, 97, 377-387. [CrossRef] 
70. Huang, W.; Xu, J.; Liu, C.; Chen, Z.; Gu, Y. Lewis Acid-Catalyzed Synthesis of Benzofurans and 4,5,6,7-Tetrahydrobenzofurans from Acrolein Dimer and 1,3-Dicarbonyl Compounds. J. Org. Chem. 2019, 84, 2941-2950. [CrossRef] [PubMed]

71. He, S.; Jain, P.; Lin, B.; Ferrer, M.; Hu, Z.; Southall, N.; Hu, X.; Zheng, W.; Neuenswander, B.; Cho, C.-H.; et al. High-Throughput Screening, Discovery, and Optimization To Develop a Benzofuran Class of Hepatitis C Virus Inhibitors. ACS Comb. Sci. 2015, 17, 641-652. [CrossRef]

72. Chong, P.Y.; Shotwell, J.B.; Miller, J.; Price, D.J.; Maynard, A.; Voitenleitner, C.; Mathis, A.; Williams, S.; Pouliot, J.; Creech, K.; et al. Design of N-Benzoxaborole Benzofuran GSK8175-Optimization of Human PK Inspired by Metabolites of a Failed Clinical HCV Inhibitor. J. Med. Chem. 2019, 62, 3254-3267. [CrossRef] [PubMed]

73. Zhang, L.; Zhang, Y.-X.; Hu, Y.; Shi, X.-B.; Jiang, Z.-Q.; Wang, Z.-K.; Liao, L.-S. Highly Efficient Blue Phosphorescent Organic Light-Emitting Diodes Employing a Host Material with Small Bandgap. ACS Appl. Mater. Interfaces 2016, 8, 16186-16191. [CrossRef] [PubMed]

74. Solórzano, P.C.; Brigante, F.; Pierini, A.B.; Jimenez, L.B. Photoinduced Synthesis of Dibenzofurans: Intramolecular and Intermolecular Comparative Methodologies. J. Org. Chem. 2018, 83, 7867-7877. [CrossRef] [PubMed]

(C) 2019 by the authors. Licensee MDPI, Basel, Switzerland. This article is an open access article distributed under the terms and conditions of the Creative Commons Attribution (CC BY) license (http://creativecommons.org/licenses/by/4.0/). 